\title{
Współczesne poglądy na temat leczenia periimplantitis - przegląd piśmiennictwa
}

\author{
Contemporary views on the treatment of periimplantitis - literature review \\ ${ }^{1}$ Katedra i Klinika Protetyki Stomatologicznej, Uniwersytet Medyczny im. Karola Marcinkowskiego w Poznaniu \\ ${ }^{2}$ Katedra i Zakład Biomateriałów i Stomatologii Doświadczalnej, \\ Uniwersytet Medyczny im. Karola Marcinkowskiego w Poznaniu
}

DOI: http://dx.doi.org/10.20883/df.2018.26

\begin{abstract}
STRESZCZENIE
Rekonstrukcje protetyczne wsparte na implantach dentystycznych są obecnie najlepszą metodą odbudowy braków zębowych. Najczęściej występującym powikłaniem mogącym prowadzić do niepowodzenia w rehabilitacji implantoprotetycznej jest periimplantitis. W terapii periimplantitis możliwych jest kilka opcji leczenia w zależności od zaawansowania stanu klinicznego.
\end{abstract}

Słowa kluczowe: periimplantitis, mucositis, terapia periimplantitis.

\section{ABSTRACT}

Prosthetic reconstructions supported by dental implants are currently the best method of restoring tooth defects. The most common complication that can lead to failure in implantological rehabilitation is periimplantitis. In periimplantitis therapy, several treatment options are possible depending on the severity of the clinical condition.

Keywords: periimplantitis, periimplant disease, mucositis, periimplantitis therapy.

\section{Wstęp}

Rekonstrukcje protetyczne wsparte na implantach dentystycznych są obecnie najlepszą metodą odbudowy zarówno pojedynczych, jak i mnogich braków zębowych [1]. Sukces implantacji szacowany jest na około $83 \%$ po 16 latach użytkowania uzupełnień protetycznych [2]. Mimo tak wysokiego odsetka powodzeń leczenia mamy do czynienia z szeregiem powikłań, które można podzielić na trzy grupy: mechaniczne, powikłania związane z niewłaściwym wykonaniem odbudowy protetycznej oraz biologiczne wczesne (przebiegające do zakończenia procesu osteointegracji) i późne (związane $\mathrm{z}$ infekcja bakteryjną w pełni zintegrowanego implantu) (Tabela 1) [3-5]. Najczęstszym z nich, zaliczanym do grupy powikłań biologicznych późnych, jest periimplantitis (PI). Częstość jego występowania sięga od 1 do nawet $50 \%$ [6].

Tabela 1. Powikłania związane z odbudowami protetycznymi wspartymi na implantach dentystycznych [3-5]

Table 1. Complications associated with implant-supported fixed dentures [3-5]

\begin{tabular}{|l|l|l|}
\hline \multicolumn{1}{|c|}{ Powikłania mechaniczne } & \multicolumn{1}{c|}{ Powikłania związane z niewłaściwą techniką } & \multicolumn{1}{c|}{ Powikłania biologiczne } \\
\hline - Uszkodzenie komponentów protetycznych & - Uszkodzenie suprastruktury odbudowy & - Niewłaściwa reakcja tkanek \\
- Złamanie implantu & - Uszkodzenie ceramiki licującej & - Zaburzenia czucia \\
- Odcementowanie pracy protetycznej & & - Utrata kości \\
& & - Utrata stabilizacji implantu \\
\hline
\end{tabular}


Periimplantitis to silny, namacalny, niszczący proces zapalny związany z implantami dentystycznymi, opisany pierwszy raz w latach 60. XX w. [7]. Obecnie określa się 2 podtypy zapalenia - periimplant mucositis - odwracalnego stanu zapalnego tkanek miękkich otaczających implant, charakteryzującego się zaczerwienieniem, obrzękiem oraz krwawieniem w trakcie sondowania i periimplantitis - proces zapalny toczący się zarówno w tkankach miękkich i twardych, prowadzący do postępującej utraty kości dookoła w pełni zintegrowanego implantu [8]. Na potrzeby niniejszej publikacji pojęciem periimplantitis (PI) oznaczamy oby dwa typy zapaleń.

W tabeli 2 zaprezentowano uproszczoną klasyfikację periimplantitis, zaproponowaną przez Rosena, w której głównym kryterium podziału jest głębokość kieszonki dziąsłowej (PD) [9].

Za czynniki ryzyka wystąpienia PI uznawane są: choroba przyzębia w wywiadzie, niezadowalająca higiena jamy ustnej, czynniki genetyczne, cukrzyca, choroby serca, leczenie immunosupresyjne, pozostawione resztki cementu (tzw. "cementitis"), przeciążenia zgryzowe, brak dziąsła zbitego czy cienki biotyp dziąsła przy implancie [10, 11].

W tabeli 3 zaprezentowano czynniki predysponujące do wystąpienia periimplantitis.

W piśmiennictwie szeroko opisywane są mikrobiologiczne podstawy schorzenia. Biofilm bakteryjny, zalegająca, dojrzewająca płytka bakteryjna to główny czynnik etiologiczny PI [12, 13]. Bakterie związane z zakażeniem tkanek okolicy implantu zaliczane są to grupy gram-ujemnych beztlenowców, odnajdywanych także w zaawansowanych stadiach choroby przyzębia [14].

W badaniach przekrojowych, w których badano skład bakteryjny kieszonek dziąsłowych zlokalizowanych przy zębach otaczających implant, w badaniu PCR wyizolowano $z$ nich głównie bakterie należące do czerwonego i żółtego kompleksu bakteryjnego wg klasyfikacji Socranskiego: Porphyromonas gingivalis, Tanarella forsythia, Fusobacterium spp, Treponema species, Prevotella intermedia, Aggregatibacter actinomycetencomitans oraz Bacteroides forsythus [15-17].

Współcześnie w terapii PI stosowanych jest kilka opcji leczenia, wywodzących się z terapii periodontitis i mających z nią wiele cech wspólnych [18]. Jednakże Terapia PI jest znacznie bardziej uciążliwa niż terapia zapaleń przyzębia. Wynika to między innymi z nieregularnej budowy mikroskopowej implantu i wysokiej zwilżalności jego powierzchni, co predysponuje do osadzania płytki bakteryjnej i utrudnia dokładne oczyszczenie jego powierzchni [19]. Celem pracy była ocena piśmiennictwa i przedstawienie współczesnych metod leczenia periimplantitis w praktyce klinicznej.

\section{Materiał i metody}

Zgromadzone piśmiennictwo pochodzi z bazy PubMed. Spośród ponad 100 pozycji wybrano zaledwie 30 o tematyce ściśle związanej z terapią

Tabela 2. Klasyfikacja periimplantitis wg Froum i Rosen (2012) [9]

Table 2. Classification of periimplantitis according to Froum and Rosen (2012) [9]

\begin{tabular}{|l|l|}
\hline Wczesne & $\begin{array}{l}\mathrm{PD} \geq 4 \text { (krwawienie i/lub wysięk rolny w trakcie sondowania) } \\
\text { Utrata }<25 \% \text { kości wokół implantu }\end{array}$ \\
\hline Umiarkowane & $\begin{array}{l}\mathrm{PD} \geq 6 \text { (krwawienie i/lub wysięk rolny w trakcie sondowania) } \\
\text { Utrata 25-50\% kości wokół implantu }\end{array}$ \\
\hline Ciężkie & $\begin{array}{l}\mathrm{PD} \geq 8 \mathrm{~mm} \text { (krwawienie i/lub wysięk rolny w trakcie sondowania) } \\
\text { Utrata > 50\% kości wokoło implantu }\end{array}$ \\
\hline
\end{tabular}

Tabela 3. Czynniki predysponujące do wystąpienia PI [20-23]

Table 3. Risk factors of PI [20-23]

- Choroba przyzębia w wywiadzie
- Niezadowalająca higiena jamy ustnej.
- Choroby ogólne (zwłaszcza cukrzyca, choroby układu krwionośnego, choroby immunosupresyjne)
- Przyczyny jatrogenne (pozostawione resztki cementu dookoła łączników
- Defekty tkanek miękkich, wąska strefa dziąsła zbitego, cienki biotyp dziąsła
- Utrata implantu lub implantów w wywiadzie
- Palenie papierosów
- Polimorfizm genotypu IL-1ß


w periimplantitis. Kryterium wyszukiwania to: periimplantitis. Wyszukiwanie ograniczono do ostatnich 10 lat.

\section{Diagnostyka i leczenie periimplantitis}

Pierwszymi objawami, które wskazują na stan zapalny w okolicy implantu jest zaczerwienienie, obrzęk tkanek miękich, wysięk ropny z kieszonki, a także dodatni wynik BoP (bleeding on probing) w trakcie sondowania kieszonek [24]. Dla jednoznacznego stwierdzenia periimplantitis konieczne jest diagnostyka radiologiczna, dla oceny stopnia zaniku kości dookoła implantu. Badanie utraty poziomu kości brzeżnej (MBL) $\leq 1 \mathrm{~mm}$ uznawane jest współcześnie jako akceptowalne, związane z remodelingiem kości po implantacji [25]. Także badanie głębokości kieszonek dziąsłowych (PD) ma duże znaczenie $w$ diagnostyce $i$ dalszym leczeniu PI. Badanie PD powinno być przeprowadzane ostrożnie, z niewielkim naciskiem (około 20N) [26]. Badanie implantów z tzw. platform switchingiem może powodować błędne wyniki i maskować rzeczywisty zanik kości [27].

W tabeli 4 zaprezentowano parametry kliniczne mogące świadczyć o periimplantitis.

Tabela 4. Wykładniki periimplantitis $\mathrm{w}$ badaniu klinicznym [32-34]

Table 4. Manifestations of PI in clinical examination [32-34]

\begin{tabular}{|l|c|}
\hline \multicolumn{1}{|c|}{ Parametry kliniczne } & Periimplantitis \\
\hline Wzrost głębokości kieszonek & + \\
\hline BoP & + \\
\hline Ropny wysięk z kieszonek & + \\
\hline Ruchomość implantu & $+/-$ \\
\hline Potwierdzony radiologicznie zanik kości & + \\
\hline
\end{tabular}

Podejrzenie $\mathrm{Pl}$, należy różnicować z:

, przeciążeniem implantu,

, błędach na etapie laboratoryjnym oraz klinicznym w trakcie odbudowy protetycznej,

, słabej jakości kości w miejscu wszczepu,

, chorobami ogólnymi oraz terapiami lekowymi, mającymi wpływ na tkankę kostną [28-31].

W każdym przypadku leczenia PI należy mechanicznie oczyścić kieszonkę dziąsłową, a prace protetyczne wykręcić na czas terapii.

Tabela 5 ukazuje uproszczony schemat postępowania przy podejrzeniu periimplantitis.

Celem każdego rodzaju terapii PI powinno być: poprawa higieny jamy ustnej pacjenta, zmniejszenie kolonii bakteryjnych, dokładne oczyszczenie powierzchni implantu oraz regeneracja kości [36].

Znanych jest kilka metod leczenia stosowanych pojedynczo bądź jako metody kombinowane. Zaliczamy do nich:

, Podaż antybiotyków działających ogólnie.

, Debridement bez lub z równoległą terapią antybiotykową ogólną.

, Debridement bez lub z lokalną podażą chemioterapeutyków i płukankami CHX.

, Debridement w połączeniu $\mathrm{z}$ terapią laserem.

, Leczenie chirurgiczne resekcyjne.

, Leczenie chirurgiczne połączone z zabiegami regeneracyjnymi [37].

W celu standaryzacji leczenia w 2004 roku wprowadzono schemat AKUT, zaprezentowany $w$ tabeli 6. Podstawowym jego założeniem jest regularna kontrola pacjenta w celu oceny ilości płytki, krwawienia, obecności stanów ropnych, kieszonek przyzębnych oraz zaniku kości widocznego na RTG. Istotne jest, aby w leczeniu coraz bardziej zaawansowanego PI nie pomijać etapów leczenia dla mniej zaawansowanych stadiów [38].

Tabela 5. Postępowanie przy podejrzeniu PI [35]

Table 5. Recommended treatment for management of periimplantitis [35]

\begin{tabular}{|c|c|c|}
\hline Czynnik podlegający ocenie & & \\
\hline \multirow{2}{*}{ Ruchomość } & Ruchomość łącznika $\rightarrow$ dokręć pracę & \\
\hline & Utrata osteointegracji $\rightarrow$ usuń implant & \\
\hline \multirow{2}{*}{$\begin{array}{l}\text { Stan tkanek miękkich } \\
\text { otaczających implant }\end{array}$} & Oceń BOP/PD/SUPP w 4 do 6 miejsc & \\
\hline & $\mathrm{PD}>5 \mathrm{~mm}+\mathrm{BOP} / \mathrm{SUPP} \rightarrow$ wykonaj RTG & \\
\hline \multirow{2}{*}{$\begin{array}{l}\text { Radiologiczny poziom } \\
\text { kości (po stronie mezjalnej } \\
\text { i dystalnej) }\end{array}$} & $\begin{array}{l}\text { Fizjologiczny zanik kości }(A B L)=1,5+0,2^{*} \text { lata } \\
\text { użytkowania implantu }\end{array}$ & \multirow{2}{*}{$\begin{array}{l}\text { Lekkie PI PBL = 0,5-1mm } \\
\text { Średniozaawansowane PI PBL = 1,1-1,5 mm } \\
\text { Zaawansowane PI PBL > 1,5mm }\end{array}$} \\
\hline & $\begin{array}{l}\text { Patologiczna utrata kości }(\mathrm{PBL})=\text { obecny stopień } \\
\text { zaniku kości - } \mathrm{ABL}\end{array}$ & \\
\hline $\begin{array}{l}\text { Potencjalne czynniki } \\
\text { jatrogenne }\end{array}$ & $\begin{array}{l}\text { Pozostałości cementu, niewłaściwa pozycja implantu, } \\
\text { niewłaściwie wykonana odbudowa protetyczna }\end{array}$ & \\
\hline
\end{tabular}

* BOP — bleeding on probing; PD — probing-pocket depth; SUPP — suppuration; ABL — amount of bone loss; PBL — pathological bone loss 
Tabela 6. Protokół AKUT wg Lang i wsp. [38]

Table 6. AKUT protocol by Lang et al. [38]

\begin{tabular}{|l|l|l|}
\hline $\begin{array}{c}\text { Stopień } \\
\text { zaawansowania }\end{array}$ & \multicolumn{1}{|c|}{ Zbadane wykładniki PI } & \multicolumn{1}{|c|}{ Leczenie } \\
\hline & PD $<3 \mathrm{~mm}$, brak płytki i BoP ujemne & Terapia niezalecana \\
\hline A & PD $<3 \mathrm{~mm}$, obecna płytka i/lub BoP dodatnie & Mechaniczne oczyszczenie, polerowanie i instruktaż higieny \\
\hline B & $\begin{array}{l}\text { PD } 4-5 \mathrm{~mm} \text {, brak zaniku kości } \\
\text { potwierdzonego zdjęciem }\end{array}$ & $\begin{array}{l}\text { Mechaniczne oczyszczenie, polerowanie i instruktaż higieny, } \\
\text { dodatkowo miejscowa terapia antybakteryjna }\end{array}$ \\
\hline C & PD $>5 \mathrm{~mm}$ utrata kości $<2 \mathrm{~mm}$ & $\begin{array}{l}\text { Mechaniczne oczyszczenie, polerowanie, testy } \\
\text { mikrobiologiczne, miejscowa i systemowa antybiotykoterapia }\end{array}$ \\
\hline D & PD $>5 \mathrm{~mm}$, utrata kości $>2 \mathrm{~mm}$ & Chirurgia resekcyjna bądź regeneracyjna \\
\hline
\end{tabular}

\section{Mechaniczny debridement/leczenie niechirurgiczne}

Mechaniczne oczyszczenie powierzchni implantu jest kluczowym zabiegiem, od którego powinna rozpoczynać się każda terapia leczenia Pl. Jego celem jest usunięcie toksyn bakteryjnych, aby stworzyć warunki do regeneracji tkanek.

Największym wyzwaniem dla tego typu zabiegów jest skomplikowana struktura implantu. $Z$ jednej strony umożliwia bardziej efektywny przebieg procesu osteointegracji, z drugiej jednak w przypadku zaniku kości dochodzi do ekspozycji części niepolerowanej implantu na nadkażenie bakteryjne, które utrudnia procesy oczyszczenia jego powierzchni.

Wśród stosowanych zabiegów mechanicznego oczyszczenia należy wymienić przede wszystkim: piaskowanie, kiretaże oraz skalingi poddziąsłowe z wykorzystaniem odpowiednich końcówek ultradźwiękowych [39].

Oczyszczania kieszonek z ziarniny zapalnej przy użyciu kiret metalowych w przypadku implantów nie są zalecane, ponieważ powodują uszkodzenie jego struktury i powstanie rys na jego powierzchni. Stosuje się specjalne kirety, w których części pracujące zostały wykonane z materiałów bardziej miękkich niż tytan (kirety plastikowe, tytanowe czy z włókna węglowego).

W wyniku zastosowania tych metod Persson, Renvert i Schwartz, zaobserwowali wyraźne zmniejszenie populacji bakteryjnej oraz redukcję wskaźnika BoP [40].

Nie wykazano natomiast znaczących różnic w skuteczności terapeutycznej skalerów piezoelektrycznych nad skalerami ręcznymi [41].

Piaskowanie powierzchni tytanowej implantu sprawia, że powierzchnia implantu jest mniej podatna na atak bakteryjny, powoduje zmniejszenie przylegania bakterii do powierzchni. Aby zwiększyć skuteczność zabiegów oczyszczania mecha- nicznego zalecane jest wykonywanie zabiegów płatowych, które umożliwiają organoleptyczną kontrolę nad oczyszczaną powierzchnią. Jak podaje piśmiennictwo po 3 miesiącach od takich zabiegów obserwuje się znaczącą poprawę wszystkich wykładników PI.

Najlepsze efekty oczyszczenia pow. implantu notowane są po zabiegu piaskowania z wykorzystaniem piasku na bazie glicyny (AAD) [42].

Jak podaje Tastepe i wsp. piaskowanie może prowadzić do reosteointegracji na poziomie 39$46 \%$ oraz zmniejszenie głębokości kieszonek dziąsłowych (PD) [43]. Zapalenie na wczesnym etapie doskonale odpowiada na tego typu zabiegi i ulega znaczącej regresji bez konieczności wprowadzania dalszych zabiegów. W przypadkach bardziej zaawansowanych stosuje się dodatkowo antybiotykoterapię lub przy niezadowalających wynikach zabiegu stosuje się metody bardziej inwazyjne.

Głównym celem mechanicznego debridementu jest zmniejszenie wskaźnika BoP.

\section{Antybiotykoterapia miejscowa}

Zastosowanie lokalnie aplikowanych antybiotyków ma wiele zalet. Możliwe jest uzyskanie bardzo wysokiego stężenia preparatów w najbardziej zainfekowanych fragmentach jamy ustnej. Dodatkowo unika się ogólnych działań niepożądanych, interakcji z innymi lekami, powstania lekooporności bakterii oraz ryzyka związanego z nieprzestrzeganiem przez pacjenta zaleceń odnośnie stosowania leków [44].

We wszystkich badaniach klinicznych znajdowanych w piśmiennictwie niezbędne było połączenie antybiotykoterapii miejscowej wraz z leczeniem niechirurgicznym.

Antybiotyki stosowane w terapii miejscowej to: nici tetracyklinowe, minocyklina, żel chlorheksydynowy oraz miejscowo podana doksycyklina. Schemat ich stosowania jest analogiczny jak w terapii chorób przyzębia [45]. 
Lokalna podaż tetracyklin, jak podają inni autorzy, wykazuje oczekiwany efekt na poprawę parametrów klinicznych i mikrobiologicznych u pacjentów prezentujących zaawansowane stany PI związane z zanikiem kości, formowaniem ropnych kieszonek dziąsłowych i PD > $5 \mathrm{~mm}$.

Przy stosowaniu żelu chlorheksydynyowego wykazano znaczącą redukcją PD, wzrost adhezji komórek do pow. implantu i poprawy wykładników stanu zapalnego, wyrażonego w zmniejszeniu markerów stanu zapalnego [46, 47].

\section{Antybiotykoterapia ogólna}

Każde leczenie farmakologiczne powinno być poprzedzone dokładnym, mechanicznym oczyszczeniem powierzchni implantu, dodatkową aplikacją 0,5\% chlorheksydyny do kieszonek dziąsłowych oraz wykonaniem antybiogramu. Jako złoty standard stosowana jest terapia amoksycyliną z kwasem klawulonowym $625 \mathrm{mg}-3$ razy dziennie $z$ metronidazolem $w$ dawce $250 \mathrm{mg}-3$ razy dziennie przez okres 10 dni. W przypadku uczulenia na penicyliny zaleca się klindamycynę $w$ dawcę $300 \mathrm{mg} 3$ razy dziennie [48].

Jak podaje piśmiennictwo, po 12-miesięcznej obserwacji zanotowano spłycenie kieszonek dziąsłowych, zmniejszenie wskaźnika BoP i zmniejszenie liczebności kolonii bakterii beztlenowych.

Dużą efektywność leczenia uzyskano w połączeniu terapii chirurgicznej z farmakologiczną. Poprzedzone były debridementem. Leonard i wsp. uzyskali skuteczność terapeutyczną na poziomie $58 \%$, przeprowadzając zabieg mechanicznego debridementu w osłonie antybiotykowej oraz następowej antybiotykoterapii [49].

\section{Leczenie chirurgiczne}

Leczenie chirurgiczne zmian zanikowych w PI powinno być stosowane w przypadku PD $>5 \mathrm{~mm}$, po wcześniejszym wyleczeniu ostrego stanu zapalnego i wprowadzeniu zabiegów higienizacyjnych przez pacjenta w warunkach domowych [50]. Przebiegać powinno łącznie z leczeniem niechirurgicznym, jako etap przygotowawczy do zabiegu. Warunkiem powodzenia terapii resekcyjnej bądź regeneracyjnej musi być eliminacja powstałych defektów kostnych (ostektomia, osteoplastyka) oraz eliminacja bakterii. Konieczna jest także tzw. implantoplastyka, czyli mechaniczne wygładzenie i dekontaminacja powierzchni implantu. Z następowym jego odkażeniem, do którego używamy kwasu cytrynowego, 3\% nadtlenku wodoru lub chlorheksydyny. Dostępne są również żele 24\% EDTA i 1\% CHX [51].
W strefie estetycznej zabiegi resekcyjne nie są zalecane z powodu dużego ryzyka wystąpienia recesji dziąsłowej [52].

Terapia resekcyjna skutkuje re-osteointegracją tylko w przypadku niewielkich, płytkich defektów. W przypadku defektów większych zalecana jest terapia regeneracyjna.

Jak podaje piśmiennictwo możliwa jest re-osteointegracja i regeneracja kości dookoła tytanowej powierzchni implantu przy wykorzystaniu auto-, allo- bądź ksenogennych przeszczepów kostnych z membraną kolagenową bądź błoną wzmacnianą e-PTFE [53].

\section{Leczenie laserem}

Leczenie $z$ użyciem lasera opiera się na działaniu termicznym. Proces prowadzi do denaturacji białka i martwicy tkanek otaczających. W stomatologii wykorzystywane są lasery Er:YAG, $\mathrm{CO}_{2}$ oraz diodowe [54].

W celu ochrony tkanek miękkich oraz powierzchni implantu użyta wiązka powinna mieć jak najmniejszą absorpcję i odbicie fali. Najlepsze wyniki uzyskano z zastosowaniem lasera Er:YAG o wiązce długości $2940 \mathrm{~nm}$. Zanotowano 90\% redukcję biofilmu. Jednakże w przeciwieństwie do mechanicznego debridementu terapia laserem prowadzi do poprawy wydolności tkanek, ale nie powoduje ich regeneracji. Laserem, który powoduje zmniejszenie populacji bakteryjnej w kieszonkach laser $\mathrm{CO}_{2}$ z długością wiązki $10000 \mathrm{~nm}$ i ustawieniach mocy 1 lub 2W [55].

Porównując metody mechanicznego debridementu i laseroterapii, terapia Er:YAG powoduje znacznie większą skuteczność w redukcji krwawienia z kieszonki podczas sondowania (BoP).

Porównując natomiast redukcję głębokości kieszonek dziąsłowych, zmniejszenie recesji dziąsłowych, zmniejszenie wskaźnika BoP oraz CAL, obie metody wykazują podobną skuteczność [56].

Mimo nieobiektywności badań, nie można pominąć laseroterapii jako skutecznego narzędzia w walce z PI, zwłaszcza jako terapia uzupełniająca [57].

\section{Podsumowanie}

Periimplantitis pozostaje powikłaniem wciąż nieprzewidywalnym, nie zawsze możliwym do leczenia, które prowadzić może do niepowodzenia $w$ rehabilitacji implantoprotetycznej. Jest to powikłanie trudne w leczeniu, podlegające długotrwałej i uciążliwej terapii, nierzadko wymagającej chirurgicznej terapii interwencyjnej.

Najskuteczniejszą terapią w walce z periimplantitis jest zapobieganie powikłaniom na każdym 
etapie leczenia oraz zachowanie zdrowych tkanek otaczających wszczepy. Niestety powikłania mogą pojawić się na każdym etapie leczenia, nawet wiele lat po udanym zabiegu.

Wzrost ryzyka powikłaniem PI spowodowane może być brakiem wnikliwego, multidyscyplinarnego planu leczenia, słabymi warunkami chirurgicznymi oraz protetycznymi, nieprzygotowaniem pacjenta do zabiegu oraz brakiem wizyt kontrolnych. Wielokrotnie w piśmiennictwie podkreślana jest także waga odpowiedniej kwalifikacji pacjenta. Należy pamiętać, że nałogowi palacze, pacjenci z zaawansowaną cukrzycą czy chorobą przyzębia w wywiadzie automatycznie zaliczani są do grupy zwiększonego ryzyka wystąpienia PI.

Niewątpliwe znaczenie w prewencji PI ma również rygorystyczne przestrzeganie zasad projektowania prac protetycznych oraz eliminacja czynników jatrogennych - dokładne usuwanie cementu z kieszonek po osadzeniu pracy, unikanie przeciążenia okluzyjnego oraz wszczepianie implantów w pozycji anatomicznej, zmniejszają ryzyko wystąpienia choroby. Regularne kontrole higienizacyjne zakończone instruktażem higieny są kluczem do sukcesu implantologicznego oraz prewencji periimplantitis.

Pomimo ciągłego wzrostu popularności leczenia implantologicznego, właściwa diagnostyka preimplantologiczna jest często pomijana. Zalecane przed zabiegiem w naszej opinii jest wnikliwe badanie kliniczne $z$ oceną parametrów, takich jak wskaźnik BoP, wartość PD, ocena higieny jamy ustnej wyrażonej wskaźnikiem API (którego wartość przed zabiegiem chirurgicznym powinna wynosić mniej niż 15\%). Tylko niskie wartości wyżej wymienonych parametrów wskazują na pacjenta świadomego i przygotowanego do zabiegu, co ma ogromne znaczenie w długotrwałym sukcesie leczenia.

Testy mikrobiologiczne dla oceny występowania rezydualnych periopatogenów rozważane powinny być u pacjentów z chorobą przyzębia w wywiadzie.

Leczenie PI powinno być skupione przede wszystkim na całkowitej eliminacji źródła infekcji, redukcji patogenów z kieszonek oraz dokładnym oczyszczeniu powierzchni implantu, aby zapewnić warunki do regeneracji tkanek miękkich i twardych.

W zależności od zaawansowania procesu $\mathrm{Pl}$, stopnia zniszczenia tkanek i odpowiedniej oceny prawdopodobieństwa powodzenia terapii dokonuje się wyboru odpowiedniej dla danego przypadku terapii. W celu ułatwienia kwalifikacji pacjenta wykorzystuje się schemat AKUT, który dyktuje terapię w zależności od nasilenia objawów PI. W badaniach modelowych w większości stosuje się metody leczenia kombinowane. Jednakże nie uzyskano jasnych wyników, które pozwoliłyby opracować pewną i całkowicie skuteczną metodę leczenia PI.

Metody niechirurgiczne wpływają na redukcję stanu zapalnego, zmniejszenie krwawienia i poprawę parametrów klinicznych. Powinny stanowić zawsze pierwszy etap leczenia chirurgicznego i leczenie z wyboru w stanach mniej zaawansowanych.

Leczenie chirurgiczne umożliwia całkowite usunięcie ziarniny zapalnej i stwarza warunki do oczyszczenia całej, odsłoniętej pow. implantu. Uzupełnieniem tej terapii powinno być także leczenie farmakologiczne. Metody regeneracyjne są natomiast jedyną skuteczną opcją leczenia zaawansowanych stanów, z dużym zanikiem kości.

Leczeniem wspomagającym jest farmakoterapia, która powinna być ustalana indywidualnie na podstawie antybiogramu.

Zadowalające wyniki leczenia uzyskano w terapii laserem. Wydaje się, że jest to najskuteczniejsza metoda małoinwazyjnego oczyszczenia powierzchni tytanowej oraz eliminacji bakterii z kieszonek. Równocześnie powoduje najmniejsze defekty powierzchni, a wytwarzane ciepło powoduje obkurczenie tkanek miękkich i wpływa stymulująco na procesy angiogenezy, a co za tym idzie lepszej administracji elementów układu odpornościowego w centrum stanu zapalnego.

Przestrzeganie schematu leczenia AKUT, poprzez jego sekwencyjną budowę, umożliwia na każdym etapie ocenę skuteczności terapii oraz stwarza możliwość oszacowania sensowności podejmowania bardziej skomplikowanych procedur leczniczych w zależności od skuteczności poprzednich kroków oraz poprzez ocenę zaangażowania pacjenta.

Dalsze badania kliniczne nad skutecznością poszczególnych metod leczenia oraz ich wpływ długoczasowy na powodzenie terapii PI są niezbędne. Liczba zabiegów implantologicznych ciągle wzrasta, ale wciąż brakuje wiedzy, specjalistów i ośrodków, jak skutecznie i szybko radzić sobie z powikłaniami wczesnymi i późnymi.

\section{Oświadczenia \\ Oświadczenie dotyczące konfliktu interesów Autorzy deklarują brak konfliktu interesów w autorstwie oraz publikacji pracy.}

Źródła finansowania

Autorzy deklarują brak źródeł finansowania. 


\section{Piśmiennictwo}

[1] Simonis $P$, Dufour T. Long-term implant survival and success: a 10-16-year follow-up of non-submerged dental implants. Clin Oral Implants Res. 2010;21:772777.

[2] Geraets W, Zhang L. Annual bone loss and success rates of dental implants based on radiographic measurements. Dentomaxillofac Radiol. 2014;43(7): 20140007.

[3] Henry PJ, Laney WR. Osseointegrated implants for single-tooth replacement: A prospective 5-year multicenter study. Int J Oral Maxillofac Implants. 1996;11:450-5.

[4] Taylor RC, McGlumphy EA. Radiographic and clinical evaluation of single-tooth Biolok implants: A 5-year study. Int J Oral Maxillofac Implants. 2004;19:84954.

[5] Hanif A, Qureshi S. Complications in implant dentistry. Eur J Dent. 2017;11(1): 135-140.

[6] Roos-Jansåker AM, Renvert H. Surgical treatment of peri-implantitis using a bone substitute with or without a resorbable membrane: a prospective cohort study. J Clin Periodontol. 2007;34:625-632.

[7] Smeets R, Henningsen A. Definition, etiology, prevention and treatment of peri-implantitis - a review. Head Face Med. 2014;10:34.

[8] Zitzmann NU, Berglundh T. Definition and prevalence of peri-implant diseases. J Clin Periodontol. 2008;35(8 Suppl):286-91.

[9] Froum SJ, Rosen PS. A proposed classification for peri-implantitis. Int J Periodontics Restorative Dent. 2012;32(5):533-40.

[10] Stacchi C, Berton F. Risk Factors for Peri-Implantitis: Effect of History of Periodontal Disease and Smoking Habits. A Systematic Review and Meta-Analysis. J Oral Maxillofac Res. 2016;7(3):e3.

[11] Canullo L, Schlee M. Group for the Study of Peri-implant Disease. International Brainstorming Meeting on Etiologic and Risk Factors of Peri-implantitis. Int J Oral Maxillofac Implants. 2015;30(5):1093-104.

[12] Schwarz F, Sahm N. Aktuelle Aspekte zur Therapie periimplantärer Entzündungen. Quintessenz. 2008;59:00.

[13] Charyeva O, Altynbekov K. A. Long-term dental implant success and survival-a clinical study after an observation period up to 6 years. Swed Dent J. 2012;36:1-6.

[14] Mellado-Valero A, Buitrago-Vera P. Decontamination of dental implant surface in peri-implantitis treatment: A literature review. Med Oral Patol Oral Cir Bucal. 2013;18(6):e869-e876.

[15] Hulting M, Gustafsson A. Microbiological findings and host response in patients with peri-implantitis. Clin Oral Implants Res. 2002;13:349-358.

[16] Al-Ahmad A, Tennert C. Antimicrobial photodynamic therapy using visible light plus water-filtered infrared-A (wIRA). J Med Microbiol. 2013;62:467-473.

[17] Meisel P, Kocher T. Photodynamic therapy for periodontal diseases: state of the art. J Photochem Photobiol B. 2005;79:159-170.
[18] Heitz-Mayfield LJ, Lang NP. Antimicrobial treatment of peri-implant diseases. J Oral Maxillofac Implants. 2004;19 Suppl:128-39.

[19] Teughels W, Van Assche N. Effect of material characteristics and or surface topography on biofilm development. Clin Oral Implants Res. 2006;17:68-81.

[20] Gruica B, Wang HY. Impact of IL-1 genotype and smoking status on the prognosis of osseointegrated implants. Clin Oral Implants Res. 2004;15:393-400.

[21] Huynh-Ba G, Lang NP. Association of the composite IL-1 genotype with peri-implantitis: a systematic review. Clin Oral Implants Res. 2008;19:1154-1162.

[22] Lagervall M, Jansson LE. Treatment outcome in patients with peri-implantitis in a periodontal clinica retrospective study. J Periodontol. 2012;84:13651373.

[23] Linkevicius T, Puisys A. Does residual cement around implant-supported restorations cause peri-implant disease? A retrospective case analysis. Clin Oral Implants Res. 2012;24:1179-1184.

[24] Albrektsson T, Isidor F. Consensus report: Implant therapy. In: Lang NP, Karring T, editors. Proceedings of the 1st European Workshop on Periodontology. Berlin: Quintessence; 1994:365-9.

[25] Mombelli A, Lang NP. Clinical parameters for the evaluation of dental implants. Periodontol. 2000. 1994;4:81-86.

[26] Duque AD, Aristizabal AG. Prevalence of peri-implant disease on platform switching implants: a cross-sectional pilot study. Braz Oral Res. 2016;30:e5.

[27] Mombelli A, Muller N, Cionca N. The epidemiology of peri-implantitis. Clin Oral Implants Res. 2012;23(Suppl 6):67-76.

[28] Zitzmann NU, Walter C. Ätiologie, Diagnostik und Therapie der Periimplantitis - eine Übersicht. Deutsche Zahnärztliche Zeitschrift. 2006;61:642-649.

[29] Mahnama A, Tafazzoli-Shadpour M. Verification of the mechanostat theory in mandible remodeling after tooth extraction: Animal study and numerical modeling. J Mech Behav Biomed Mater. 2013;20:354-362.

[30] Georgiopoulos B, Kalioras K. The effects of implant length and diameter prior to and after osseointegration: a 2-D finite element analysis. J Oral Implantol. 2007;33:243-256.

[31] Misch CE, Perel ML. Implant success, survival, and failure: the International Congress of Oral Implantologists (ICOI) Pisa Consensus Conference. Implant Dent. 2008;17(1):5-15.

[32] Kadkhodazadeh M, Amid R. Evaluation of peri-implant tissue health using a scoring system. JIACD. 2012;4:51-7.

[33] Sanz M, Chapple IL. Working Group 4 of the VIII European Workshop on Periodontology. Clinical research on peri-implant diseases: consensus report of Working Group 4. J Clin Periodontol. 2012;39(Suppl)12:202-6.

[34] Ramanauskaits A, Juodzbalys G.Diagnostic Principles of Peri-Implantitis: a Systematic Review and Guidelines for Peri-Implantitis Diagnosis Proposal. J Oral Maxillofac Res. 2016;7(3):e8. 
[35] Prathapachandran J. Suresh N. Management of peri-implantitis. Dent Res J (Isfahan). 2012;9(5): 516-521.

[36] Hsu A, Martin Kim JW. How to Manage a Patient with Peri-implantitis. J Can Dent Assoc. 2014;79:e24.

[37] Lang NP, Berglundh T. Consensus statements and recommended clinical procedures regarding implant survival and complications. Int J Oral Maxillofac Implants. 2004;19(Suppl):150-154.

[38] Renvert S, Samuelsson E. Mechanical non-surgical treatment of periimplantitis: a double-blind randomized longitudinal clinical study. I: clinical results. J Clin Periodontol. 2009;36:604-609.

[39] Persson GR, Samuelsson E. Mechanical non-surgical treatment of periimplantitis: a single-blinded randomized longitudinal clinical study. II. Microbiological results. J Clin Periodontol. 2010;37:563-573.

[40] Karring ES, Stavropoulos A. Treatment of periimplantitis by the Vector system. Clin Oral Implants Res. 2005;16:288-293.

[41] Tastepe CS, Liu Y. Cleaning and modification of intraorally contaminated titanium discs with calcium phosphate powder abrasive treatment. Clin Oral Implants Res. 2012;24:1238-1246.

[42] Tastepe CS, Liu Y. Cleaning and modification of intraorally contaminated titanium discs with calcium phosphate powder abrasive treatment. Clin Oral Implants Res. 2012;24:1238-1246.

[43] Aved F, Alghamdi AS.T. Clinical efficacy of antibiotics in the treatment of peri-implantitis. Int Dent J. 2013;63:169-176.

[44] Renvert S, Lessem J. Topical minocycline microspheres versus topical chlorhexidine gel as an adjunct to mechanical debridement of incipient peri-implant infections: a randomized clinical trial. J Clin Periodontol. 2006;33:362-369.

[45] Bassetti M, Schär D. Anti-infective therapy of peri-implantitis with adjunctive local drug delivery or photodynamic therapy: 12-month outcomes of a randomized controlled clinical trial. Clin Oral Implants Res. 2013;25:279-287.

[46] Shrestha B, Theerathavaj ML.S. In vitro antimicrobial effects of grape seed extract on peri-implantitis microflora in craniofacial implants. Asian Pac J Trop Biomed. 2012;2:822-825.

[47] Mombelli A, Lang NP. Antimicrobial treatment of peri-implant infections. Clin Oral Implants Res. 1992;3(4):162-8.
[48] Leonhardt A, Dahlén G. Five-year clinical, microbiological, and radiological outcome following treatment of peri-implantitis in man. J Periodontol. 2003 Oct;74(10):1415-22.

[49] Schmage P. Befundorientiertes Behandlungskonzept bei periimplantären Infektionen. Parodontol. 2010;21:339-358.

[50] Jovanovic S. The management of peri-implant breakdown around functioning osseointegrated dental implants. J Periodontol. 1993;64:1176-83.

[51] Chen S, Darby I. Dental implants: Maintenance, care and treatment of peri-implant infection. Aust Dent J. 2003;48:212-20.

[52] Schou S, Berglundh T. Surgical treatment of peri-implantitis. Int J Oral Maxillofac Implants. 2004;19(Suppl):140-9.

[53] Schwarz F, Rothamel D. Einfluss eines Er:YAG-Lasers auf die Oberflächenstruktur von Titanimplantaten. Klinische Fallberichte. Schweiz Monatsschr Zahnmed. 2003;113:660-671.

[54] Kim JH, Herr Y. The effect of erbium-doped: yttrium, aluminium and garnet laser irradiation on the surface microstructure and roughness of double acid-etched implants. J Periodontal Implant Sci. 2011;41(5):234-241.

[55] Romanos GE, Gutknecht N. Laser wavelengths and oral implantology. Lasers Med Sci. 2009;24:961-970.

[56] Smeets R, Ralf h. Definition, Etiology, Prevention and Treatment of Peri-Implantitis - a Review. Head \& Face Medicine. 2014;10:34.

Zaakceptowano do edycji: 2018-10-16 Zaakceptowano do publikacji: 2018-12-05

Adres do korespondencji:

Magdalena Nowak

Katedra i Klinika Protetyki Stomatologicznej

Uniwersytetu Medycznego im. Karola

Marcinkowskiego w Poznaniu

ul. Bukowska 70, 60-812 Poznań

e-mail: magdalena.nowak@ump.edu.pl 